\title{
The Celt and the Sea
}

\section{Author(s): Kenneth Macleod}

Source: The Celtic Review, Vol. 3, No. 11 (Jan. 15, 1907), pp. 242-251

Stable URL: http://www.jstor.org/stable/30023309

Accessed: 28-06-2016 05:12 UTC

Your use of the JSTOR archive indicates your acceptance of the Terms \& Conditions of Use, available at

http://about.jstor.org/terms

JSTOR is a not-for-profit service that helps scholars, researchers, and students discover, use, and build upon a wide range of content in a trusted digital archive. We use information technology and tools to increase productivity and facilitate new forms of scholarship. For more information about JSTOR, please contact support@jstor.org. 
Point of Staffpoint. Dunstaffnage, again, is the Fort of Staffpoint.

5. In composition with the preposition fo used adjectivally, innis gives Foineis, sub-meadow, small meadow, or possibly, under-meadow, appearing in English as Foynes, Phoineas, Fynes. This rather difficult name has been explained as from eas, a waterfall; fo an eas, under the fall; but in point of fact, in two of the three places bearing the name with which I am familiar (Nairn, Beauly, Abriachan), there is no waterfall, and there never was one. For the sense may be compared the common Fowlis, G. Fólais from fo-ghlais, sub-stream ; also Foyers, Gaelic Foithir, in plural na Foithrichean, flat land lying under a steep declivity. In Stratherrick there are two or three places of this name, apart from the famous waterfall, which is in Gaelic Eas na Smuid, Sprayfall.

\section{THE CELT AND THE SEA ${ }^{1}$}

\section{Kenneth Macleod}

Probably the Islesmen owe their love of the sea even more to their Norse than to their Celtic blood. The old Celts regarded the sea as a dark, mysterious power, cruel as an evil woman, ${ }^{2}$ but most effective as a protection against their enemies. The Norsemen, on the other hand, thought of the sea rather as 'the path to glory'; beyond the waves were strange lands and boundless wealth, waiting to be claimed by men of the necessary daring. In short, in their attitude towards the sea, the Celt was the better poet, the Norseman the better sailor. In their common descendants the two traits are combined; the Norse love of the sea has been deepened and variegated by Celtic fervour and imagination. Thus, of all subjects, the one dearest to the Hebridean poet

1 It has been thought unnecessary to give the Gaelic text of the quotations used in the above paper, as the poems from which the extracts are taken will be published in full in future numbers of the Review.

2 See Campbell's Tales of the West Highlands. 
is 'the ship at sea'-the ocean in its ever-changing moods, and the ship in its eternal contest with the waves. The descriptions of this contest are, as a rule, delightfully exaggerated, but graphic as only a true sea-dog could make them :-

\author{
- Far travels the noise of the boat \\ Galloping through the Sea of Erin; \\ Far travels the noise of her leaps \\ As she bounds through the swelling ocean; \\ Wind and tide and the fury of the deep \\ Hurl themselves against the darling; \\ But the rare Macleod is at the helm, \\ The bellowing wave to him is music.' 1
}

And so, with a good helmsman, the boat defies the combined efforts of all the elements, and reaches her destination in safety. Such was the luck of Alexander Macdonald's famous 'Barge of Clan-Ranald'-such also the luck of the 'Iubhrach Ur,' the New Barge, so popular in Hebridean folk-song :-

'Goes she through Caol Muile fawnlike,
Then across to Eilean Uaine,
Back in gallop o'er to Moidart,
Past the hilly isles of caves,
Past the mountains dark and frowning,
Past the reefs so low and cold,
And athwart through mountain-billows
To the Brindled Isle of brave men
To the Sunny Isle of fair ones;
O many a dark point has she rounded,
Many a gray limpet pounded,
Many a curving whelk powdered,
As she gallops through the silent straits.'

1 A Skye sea-song. It may be said here that most of the quotations used in this paper are from unpublished Gaelic poems collected by the writer in Skye, Eigg, and Uist. The translations are practically literal, and reproduce as nearly as possible the rhythm, though not the rhyme, of the original.

2 From a popular Gaelic sea-song, called 'The New Barge.' The course taken by the boat is easily identified-through the Sound of Mull to Islay (or Erin ?), thence back to Moidart, and by Eigg and Rum across to Uist and Harris. 
Every boat, however, is not equally lacky. Though the sea, being strong and generous, seldom pushes matters to an extreme, especially when the boat shows pluck, yet there are other enemies to be reckoned with, such as the mean, cowardly rocks, which lurk and crouch under the waves, and never show themselves in the light of day. 'A new boat and old rocks,' so the Gaelic proverb tersely describes the conflict between the two. The rocks are old and cunning and unscrupulous, the boat is young and simple and unsuspicious, and so a thousand tragedies follow, and the Gaelic folk-songs become ever softlier and sadlier.

The wife sits in her lonely hall and croons to her only child the story of her widowhood ${ }^{1}$ :-

\footnotetext{
'I see the barge within the creek

Sweethearting with winds and waves.

When she sailed out to the deep

Never a teal-duck ${ }^{2}$ greeted her
}

But a raven ever on her track-

O pity those at sea to-night!'

And though the trembling woman ashore tries to counteract the raven's influence by reciting the old charm :-

'Fire and water on thy wing,

The curse of God in beak and flight,'

yet what is fated must happen, and the boat with all on board goes down :-

' Rest to their souls, a place in Glory,

A good reception from King and Virgin.'

The sweetheart again sits on a rock by the seashore and questions the seagulls as to the fate of her sailor-lad and his gallant $\mathrm{crew}^{3}$ :-

1 A Macleod of Harris lullaby.

2 A bird of good omen.

3 From an old ballad still sung in the Hebrides. 
THE CELT AND THE SEA

' Little seagull, ocean seagull,

Snow-white seagull, what thy tidings?

Where, $\mathrm{O}$ where, are the fair young lads?'

And the seagull makes answer :-

'I left them all in the ocean-depths,

Face to face, and each one lifeless.

Back to back, and red blood flowing-

Their pillow to-night the soft seaweed.'

And the maiden wishes that she too were there :-

'Side by side, my sweetheart and I,

Never to move and never to part,

Ever falling asleep, our companionship quiet.'

Another, to whom even the seagulls could bring no tidings, good or bad, of her dear one, cries out pathetically ${ }^{1}:-$

' $O$ Virgin, pity me to-night

If his shroud be the tangle,

If his couch a sandy hollow,

If the seals his wake-attendants,

If the fish his waxen candles,

If his harp the croon of waves.'

Nor less sincere is the grief of the sister as she thinks of three young brothers who will never again put into port, though their boat was one of the rarest ever built ${ }^{2}$ :-

' When she getteth up her white sails

Fairer she than the young Bride of Clan-Ranald.

Never a wave in strait or ocean

But dances with joy when she puts to sea.

Never a seal or brindled teal-duck

But seeks to follow in her wake.

She goes to Uist and she goes to Lewis

And across to Rōdel in Harris.'

1 A sea-song associated with the Macleods of Dunvegan.

2 This ballad is still popular with the old folk of Skye, Eigg, and Uist. 
But so fair and swanlike is the boat that the wild Minch falls in love with her, and, mad with jealousy, suffers her not to return to land :-

' Covets her, the Sea of Skee, ${ }^{1}$

Nor allows her visit shore.'

And thus it is that-

'She reaches not Uist, she reaches not Lewis, She reaches not Rōdel in Harris.'

In spite of the tragedies, however, the love of the sea runs strongly in the Hebridean blood, and frequently becomes quite a passion. ' $O$ for one glimpse of the Western Sea' is the constant cry of the islander whom fate has placed in the heart of the mainland, with the unfeeling mountains around him. To this Ionndrain-cuain, Sea-longing, Gaelic poetry owes some of its most exquisite verses :-

'Deep the longing that has seized me,

Song nor fiddle chase it off-

In my ear resounds the ocean,

The sea-voices call me home.

$\mathrm{O}$ sun on high, 'tis little wonder

The glory of joy light up thy face-

From the glen and night thou glidest

To embrace the Western Sea.

$O$ were it mine, thy westward journey,

Sure I'd never glide so slow-

Yet to-night thou 'lt kiss the ocean,

While over me the mountains frown.' 2

And if the old proverb can be trusted, this affection is mutual. 'The sea invites acquaintance,' and out of this acquaintanceship springs a friendship which, on the side of man, is stronger than the fear of death; and on the side of

1 The minch between Skye and Uist.

2 From an old Gaelic song rescued in Eigg. It is said to have been composed by a daughter of Macneill of Barra, who had married a mainland chief, and consequently lived far away from the Isles and the Western Sea. 
the sea is as generous as it is sometimes rough-so generous indeed that, to the Barra fisherman, the Western Ocean has become Cuile Mhoire, the Virgin Mary's Treasury. That there are limits to her generosity, every Celt knows; she is extremely jealous of her rights, the most sacred of which is perhaps the custody of her dead. 'The sea,' says an old Gaelic rhyme, 'will search the four russet divisions of the universe to find the graves of her children.' Hence a body washed ashore should be buried as near the water-mark as possible, so that the sea may 'recover her own,' if such be her will. The neglect of this rule is supposed to have been the cause of many a memorable flood in the Hebrides-old Mother Ocean rushing inland to claim her own. And if the physical difficulties should prove too much for her, she wakens out of their long sleep a few golden-haired vikings and sends them ashore to do her bidding. In the early years of the nineteenth century, the North Uist people, on a day still spoken of, reverently laid in their ancient Temple of the Trinity an unknown body washed ashore by the flowing tide; at twilight a mysterious-looking barge glided into the bay, three of its crew marched up silently to the temple, opened the newly-made grave, carried off the body, and then disappeared for ever into the darkness and the great open sea. ${ }^{1}$

One can easily understand how, with such spirits and mysteries, the sea has cast her spell upon the impressionable Celt, and has given his songs and stories a colour which is not of this world. Her generosity, her might, her playfulness, her frequent cruelty, each is duly dwelt upon; but what really haunts the Celtic mind is her awful mysteriousness. There is scarcely a rock or creek or headland in the west which is not glorified by some tale of the supernatural, told with the artless art which makes realism. In the island of Eigg, when the autumn moon is full, the young people still go down to the shore to dig for sand-eels, and to pass a merry

1 Told to the writer by an old man in North Uist, who declared that several of his acquaintances had been present at the unknown one's burial. 
hour of song and dance. One at any rate of these occasions has been made memorable by a story and a ballad, ${ }^{1}$ in the lines of which one hears the roll of the mysterious sea breaking on far-away shores :-

\footnotetext{
'One night was $I$ in the eel-shore,

I saw the moon in the heavens,

I sang my rune in the name of the Triune,

I blessed myself and all my dear ones.

She came to me, the fair one of the noble face,

She spoke to me in words sweet and low.

"Thou art the glad but I the sad woman,

I have lost the ship, I have lost my Diarmid,

I have lost my son, the fair-young, ever-young.

I have sought him up, I have sought him down,

I find not the trail of my nursling.

In the isle of the sweet-voiced maidens,

In the cave of the slimy reptiles,

Late and early a-seeking him,

At ebb-tide and flow-tide a-seeking him,

A-seeking my lost one, Diarmid,

A-seeking him, ever a-seeking and yearning."

'I sang my rune in the name of the Triune,

I blessed myself and all my dear ones.

She vanished, the fair one of the noble face.

But I heard a weeping in the heavens,

I heard a shrieking in the nether-sea:

"My fair young love, my Diarmid,

Accursed am I, and ever hell-tortured,

A-seeking thee, ever a-seeking and yearning,

My fair young love, my Diarmid,

O my fair young love, my Diarmid."'
}

Perhaps the Eigg people were greater dreamers than others, at any rate they frequently saw things it was hardly lawful for mere mortals to see. Not so many years ago, ${ }^{2}$ for instance, a few of the more gifted ones actually saw a longtheine, a fire-ship, careering past the isles with lightning speed, ' and on the deck was a long, lean, black creature, with

1 Picked up from an old woman in Eigg several years ago.

2 The writer was a boy in the Island of Eigg at the time. 
a fiddle in his hand, and he ever playing and dancing and laughing-and $O$ St. Mary and my love, awful was the howling that was below!'

Such the mysteriousness of the sea which makes Eigg an isle of dreams ; doubtless the fire-ship was conveying the soul of some unrighteous Southern lord ' to its own place.'

A more pleasing picture is that of the White Ship, as of crystal, in which the pre-Christian Celt sailed to his IslandHeaven far out in the Western Sea. The Celtic hope indeed, whether in Christian or in Pagan times, ever lies in the west and the sea; there the sun sets in the evening to rise again in a morning which may tarry but will surely come.

\footnotetext{
' On the hillside I recline

Ever yearning for the lost,

Ever looking to the west,

Where the sun sets in the sea.' ${ }^{1}$
}

Very curiously, however, the Celtic Heaven or Hope has from the first been limited by a Doctrine of Election; in Pagan $^{2}$ as well as in Christian times some were 'chosen' and others not, and the deciding factor was the will of the otherworld rather than the conduct of man. Possibly the explanation is that Celtic religion, whether Christian or pre-Christian, has been largely coloured by the influence of the sea. The God of the Celt was as the Atlantic, infinite and eternal, terrible in anger, never to be trifled with, mysterious in His actions, harsh to one and gentle to another. Men who knew from experience how one boat reached her harbour in safety while the other went down, how the sea brought wealth to one family and death to another, would be more likely than most to believe and even find comfort in such a doctrine as Predestination. In religion, however, as in everything else, the old Celtic world is fading away before the modern and the 'rational.' All this may be 'progress,' but it is doubtful

1 From one of the Grelic songs of the late Dr. Maclauchlan, poet, physician, and Morvenite!

2 See 'Echtra Condla Chaim' in Journal Arch. and Hist. Association, 1874, p. 118. 
if the race has been improved thereby; at any rate one may be pardoned for preferring the old Celt to the new, and lamenting the passing away of the deep-souled hero who, trusting equally in his religion and his dirk, met life and death as a boat meets the waves. Even in these degenerate days, there are a few Celtic dreamers who, when the night is dark and the wind high, close their eyes and picture to themselves the Clan-Ranald Barge rushing through the Western Sea, the watchman chaunting 'The Dawn-Prayer.'

'Fragrant maiden of the sea,

Thou art full of the graces,

And the Great White King is with thee.

Blessed art thou, blessed art thou,

Blessed art thou among women;

Thy breath steering my prayer,

It will reach the Haven White;

Let me beseech thy gentle Son

To whom thou gavest knee and suck

To be with us,

To be on wateh,

To be awake;

' To spread over us His Sacred Cowl

From ray-light to ray-light,

From the golden-yellow ray of twilight

To the new-born white ray of dawn,

And through the dark and dangerous night

To succour us,

To guide us,

To shine on us

With the guidance and glory of the nine rays of the Sun,

Through seas and straits and narrows

Until we come to Moidart

And the Good Clan-Ranald,

O until we come to Moidart

And the Good Clan-Ranald.'

And if the few Celtic dreamers who hear the DawnPrayer in the darkness and the storm should have, as they must have, the dramatic instinct, they will see also another

1 The above version of the Clan-Ranald sea-prayer (usually called the DawnPrayer) was picked up by the writer in the Island of Eigg. 
THE CELT AND THE SEA

boat lurking somewhere near hand, haughty Macleods on board - the clan of fire and music-voices and waves blending together as the Dunvegan sea-hymn ${ }^{1}$ is chaunted forth triumphantly:-

' Thou who dwellest

In the heights above,

$O$ succour us in the depths below;

Vouchsafe to us a day-breeze

As Thou Thyself wouldst wish,

Vouchsafe to us a night-breeze

As we ourselves would choose.

May the clouds hide us,

May the moon shine on the foe,

Be we to windward

And becalmed be they;

$O$ keep firmly tethered

All sudden blasts and accidents-

And leave the rest to us

And to our daggers true,

$O$ leave the rest to us

And to our daggers true-

And we shall give the glory

To the Trinity and Clement

And the great clerk who lives in Rōdel.' ${ }^{2}$

To-day in the Western Sea, instead of the galley one sees the motor-boat, and instead of the 'Dawn-Prayer' or 'Dunvegan Hymn' one hears the latest music-hall ditty; but still the sea remains and the Celt remains, and in dreams at any rate-

'A ship that goes a-sailing

With the young through the straits,

In search of adventure and danger,

The music of laughter and love.' 3

1 Rescued in the Island of Eigg by the writer.

2 Rōdel, in the Island of Harris, was in olden times the Iona of the Clan Macleod ; there, in the old church dedicated to St. Clement, the patron-saint of the clan, their dead were buried and the living 'paid their vows.'

3 Old Gaelic song. 